\title{
Taxonomy of Fuzzy Multi-Attribute Decision Making Systems in Terms of Model, Inventor and Data Type
}

\author{
Rusydi Umar \\ Department of Informatics Engineering \\ Universitas Ahmad Dahlan \\ Yogyakarta, Indonesia \\ rusydi_umar@rocketmail.com
}

\author{
Sunardi \\ Department of Electrical Engineering \\ Universitas Ahmad Dahlan \\ Yogyakarta, Indonesia \\ sunardi@mti.uad.ac.id
}

\author{
Yasinta Bella Fitriana \\ Department of Informatics Engineering \\ Universitas Ahmad Dahlan \\ Yogyakarta, Indonesia \\ yasintabella13@gmail.com
}

\begin{abstract}
Decision support systems are one of the choices decision-makers make in an attempt to cope with the problems related to the time length required in decision-making process. Such systems are known to improve the efficiency and accuracy in the decision-making processes. In developing a decision support system, a certain calculation method is required as part of its processing. One of the most commonly used methods is FMADM. This research discusses the clustering of decision support system using FMADM in an attempt to provide a taxonomy of decision support system based on FMADM.
\end{abstract}

Keywords-artificial intelligence; decision support system; fuzzy; taxonomy

\section{INTRODUCTION}

A decision support system (DSS) is a computerized system that will provide results in the form of ranking based on the assessment aspects determined by decision makers. DSSs are derived from expert systems and are part of the artificial intelligence (AI) field and of the applications that aim to help solving common knowledge-based cases [1]. DSSs are systems that try to gather and exploit human knowledge and experience in artificial intelligence systems so that they may assist in, or even perform, decision making [2]. Some examples of research on expert systems are stroke detection [3], animal disease identification [4, 5] and motor engine damage detection [6]. One of the algorithms used in DSSs is the Multiple Criteria Decision Making (MCDM) algorithm. However, MCDM is divided into several types. This paper, following a similar approach to the one in [7], provides a short literature review on MCDM taxonomy focusing on Multi Attribute Decision Making (MADM) aiming to provide a taxonomy of Fuzzy Multi-Attribute Decision Making Systems in Terms of Model, Inventor, and Data Type Methods.

\section{RESULT AND DISCUSSION}

MCDM is a decision-making method that can be used to establish the best choice from a number of alternatives based on certain criteria, e.g. size, standard etc [8]. However, MCDM has a minor disadvantage: if the data provided by the decision maker or the attribute of the data is incomplete, then the resulting decision will contain uncertainty. The problem of uncertainty can be caused by several things, namely: 1 .
Information that cannot be calculated, 2. Incomplete information, 3. Unclear information and 4. Partial abandonment [9]. To solve these problems, some research on the use of Fuzzy MCDM began to be conducted in order to find methods that proved to have excellent performance. FMCDM can be divided into 2 models: fuzzy multi objective decision making (FMODM) and fuzzy multi attribute decision making (FMADM). FMADM model then can be further divided into 2 models namely the Yager and the Baas \& Kwakernaak model. Based on the type of data, FMADM can be divided into 3 types, namely fuzzy data, crisp data, fuzzy and crisp data [10]. While based on the method of application, FMADM can be divided into 3 types, namely SAW method, WP method and TOPSIS. FMADM taxonomies are shown in Figures 1-4 and are presented below.

\section{A. FMADM Inventor-Based Taxonomy}

1) Yager Model

The Yager model FMADM is the standard form of FMADM. According to [11],Yager model has 5 completion stages, which are:

1. Set a pairwise comparison matrix between attributes $M$ based on Saaty's hierarchy procedure.

2. Determine the consistent weight of $\mathrm{w}_{\mathrm{j}}$ for each attributes for each attribute based on the eigenvector method of Saaty.

3. Calculate the value of $\left(\tilde{C}_{j}\left(x_{i}\right)\right)^{w_{i}}$

4. Determine the intersection of all $\left(\tilde{C}_{j}\left(x_{i}\right)\right)^{w_{i}}$

5. Select $x_{i}$ with the largest membership degree in $\widetilde{D}$, and set the optimal alternatives.

One of the researches related to DSS using Yager method is [12] which emphasize on theapplication of DSS to solve cases about the determination of families as poor. A similar research, [13], was conducted to solve the best customer selection case. Both researches resulted in a desktop-based decision support system that was able to assist the decision-making process in their respective cases. 


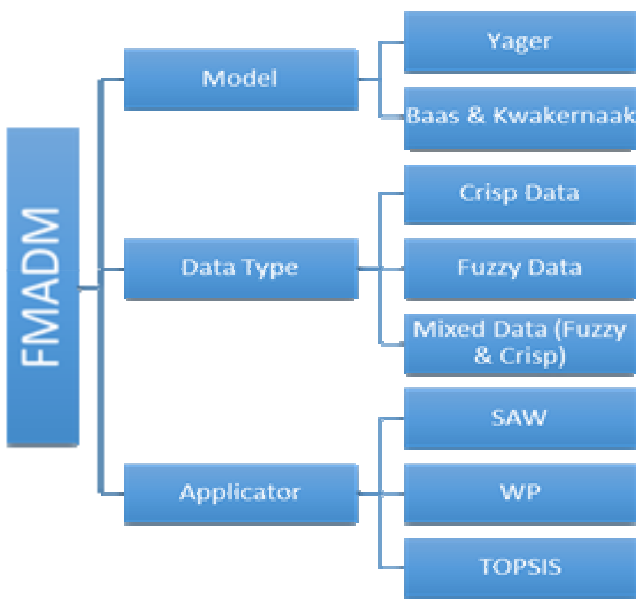

Fig. 1. FMADM taxonomy

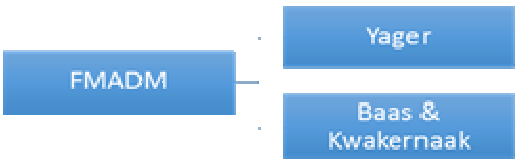

Fig. 2. FMADM inventor-based taxonomy

\section{2) Baas \& Kwakernaak Model}

In contrast to the Yager model, the Baas \&Kwakernaak model is not a standard form of FMADM, but the concept is often used by some researchers for further development [10]. The Baas \&Kwakernaak model is a method that describes the ranking of some aspects of an alternative using fuzzy sets[14].According to[11]Baas and Kwakernaakmodel contains the following steps:

1. Evaluate each alternative $a_{i}$, through function $g$ as follows:

$$
g_{i}(z)=\frac{\sum_{j=1}^{m} w_{j} r_{i j}}{\sum_{j=1}^{m} w_{j}}
$$

where $\mathrm{w}=\left(\mathrm{w}_{1}, \ldots, \mathrm{w}_{\mathrm{m}} ; \mathrm{r}_{1}, \ldots, \mathrm{r}_{\mathrm{m}}\right)$. The membership function of $\mu_{\mathrm{Zi}}$ is defined as follows :

$$
\mu_{Z i}=\min \left\{\min _{j=1, . . m}\left(\mu_{W j}\left(w_{j}\right)\right){ }_{,} \min _{k=1, \ldots m}\left(\mu_{R i k}\left(r_{k}\right)\right)\right\}
$$

Through the $g$ function, the fuzzy set $\tilde{Z}=\mathfrak{R}^{2 m},\left(\mu_{z i}\right)$ will be brought to a fuzzy $\operatorname{set} \widetilde{R}_{i}=\left(\Re, \mu_{\tilde{R} i}\right)$ with membership function:

$$
\mu_{\bar{R} i}=\sup \left(\mu_{Z i}(z)\right)
$$

The value $\left.\mu_{\bar{R} i}=(\bar{r})\right)$ is an alternative end value $\mathrm{a}_{\mathrm{i}}$.

2. The best alternative is chosen as follows:

$\left\{i \in I \mid \bar{r}_{j} \geq \bar{r}_{j}, \forall j \in I\right\}$, and $I=\{1, \ldots, n\}$.

\section{B. FMADM Data-Type-Based Taxonomy}

1. Crisp data, also called standard data is the original data obtained directly from the source [15] and grouped by their respective attributes. Use of crisp data is considered less suitable.
2. Fuzzy data, this data is chosen as the solution to overcome the problem of uncertain decision maker's request. In this case the fuzzy data is crisp data that has been transformed into fuzzy set. The fuzzy set [16] is a generalization of the concept of a characteristic function, the fuzzy set has an unclear boundary with its membership value being in the range 0 to 1 [15].

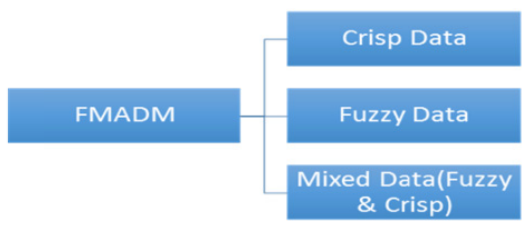

Fig. 3. FMADM data-type-based taxonomy

\section{FMADM Applicator-Based Taxonomy}

\section{1) Simple Additive Weighting (SAW)}

SAW[17] is known as the linear weighting combination or the most commonly used valuation methods for making simple multi-attribute decisions. The basic concept is to find a weighted sum of performance ratings on each alternative on all attributes[10]. SAW method requires the process of normalizing the decryption matrix $(\mathrm{x})$ to a scale proportional to all alternative judgments. The normalized formula is as follows [18] :

$r_{i j}=\left\{\begin{array}{lr}\frac{x_{i j}}{\operatorname{Max}_{i} x_{i j}} & j \text { is the attribute of benefit } \\ \frac{\operatorname{Min}_{i} x_{i j}}{x_{i j}} & j \text { is the attribute of cost }\end{array}\right.$

where $r_{i j}$ is the normalized performance rating of the $A_{i}$ alternatives in the attribute $C_{j} ; i=1,2, \ldots, m$ and $j=1,2, \ldots, n$. The preference value for each alternative $\left(\mathrm{V}_{\mathrm{i}}\right)$ is given as:

$$
V_{i}=\sum_{j=1}^{n} w_{j} r_{i j}
$$

A larger $V_{i}$ value indicates that the $A_{i}$ alternative is preferred/chosen.

\section{2) Weighted Product (WP)}

The WP method [19] uses the normalization process, where the rating of each attribute must be raised first with the corresponding attribute weights. This process is given by (7).

$$
S_{i}=\prod_{j=1}^{n} x_{i j}{ }^{w_{j}}
$$

Where $\mathrm{i}=1,2, \ldots, \mathrm{m}, \mathrm{S}$ represents an alternative preference, $\mathrm{x}$ denotes the criterionvalue, $w$ denotes the criterion's weight, $n$ denotes the criteria number. The rank $\mathrm{w}_{\mathrm{j}}$ is a positive-valued rank for the attribute of gain, and is negatively valued for the attribute of cost. The relative preferences of each alternative can be given as :

$$
V_{i}=\frac{\prod_{j=1}^{n} x_{i j}{ }^{w_{j}}}{\prod_{j=1}^{n}\left(x_{j}^{*}\right)^{w_{j}}}
$$

Where $\mathrm{V}$ denotes alternative preferences, $\mathrm{x}$ denotes the value of criteria, and $w$ denotes the weight of criteria. 
3) Technique for Order Preference by Similarity to Ideal Solution (TOPSIS)

TOPSIS is a multi-criteria method to identify solutions of limited alternatives. The basic principle is that the chosen alternative must have the shortest distance from the ideal positive solution and the furthest distance from the ideal negative solution [17]. In general, TOPSIS procedures can desribed as follows [10]:

1. Create a normalized decision matrix

2. Create a weighted normalized decision matrix

3. Determe the matrix of positive ideal solutions and matrices of negative ideal solutions;

4. Determine the distance between the value of each alternative with positive ideal solution matrix and negative ideal solution matrix;

5. Determine the preference value for each alternative.

TOPSIS requiresperformance rating of each alternative $A_{i}$ on each of the normalized $\mathrm{C}_{\mathrm{j}}$ criteria, namely:

$$
r_{i j}=\frac{x_{i j}}{\sqrt{\sum_{i=1}^{m} x_{i j}^{2}}}
$$

where $i=1,2, \ldots, m$; and $j=1,2, \ldots, n$.The ideal positive solution $\mathrm{A}^{+}$and the ideal negative solution $\mathrm{A}^{-}$can be determined based on the normalized weighted rating $\left(\mathrm{y}_{\mathrm{ij}}\right)$ as:

$$
y_{i j}=w_{i} r_{i j}
$$

where $i=1,2, \ldots, m$; and $j=1,2, \ldots, n$.

$$
\begin{aligned}
& \mathrm{A}^{+}=\left(y_{1}^{+}, y_{2}^{+}, \ldots, y_{n}^{+}\right) \\
& \mathrm{A}^{-}=\left(y_{1}^{-}, y_{2}^{-}, \ldots, y_{n}^{-}\right)
\end{aligned}
$$

Whereas

$$
y_{j}^{+}=\left\{\begin{array}{l}
\max _{i} y_{i j} ; \text { if } j \text { is the attribute of benefit } \\
\min _{i} y_{i j ; \text { if } j \text { is the attribute of cost }}
\end{array}\right.
$$

and

$$
y_{j}^{-}=\left\{\begin{array}{c}
\min _{i} y_{i j} ; \text { if } j \text { is the attribute of benefit } \\
\max _{i} y_{i j ; i \text { if } j \text { is the attribute of cost }}
\end{array}\right.
$$

wherej $=1,2, \ldots$.

The distance between alternative $A_{i}$ with the ideal positive solution is formulated as:

$D_{i}^{+}=\sqrt{\sum_{j=1}^{n}\left(y_{i}^{+}-y_{i j}\right)^{2}} ;$ where $i=1,2, \ldots, m$

The distance between alternative $A_{i}$ with the ideal negative solution is formulated as:

$D_{i}^{-}=\sqrt{\sum_{j=1}^{n}\left(y_{i j}-y_{i}^{-}\right)^{2}} ;$ where $i=1,2, \ldots$,

The preference value for each alternative $\left(\mathrm{V}_{\mathrm{i}}\right)$ is given as:

$$
V_{i}=\frac{D_{i}^{-}}{D_{i}^{-}+D_{i}^{+}} ; \text {where } i=1,2, \ldots, m
$$

A larger $V_{i}$ score indicates that $A_{i}$ alternatives are preferred.

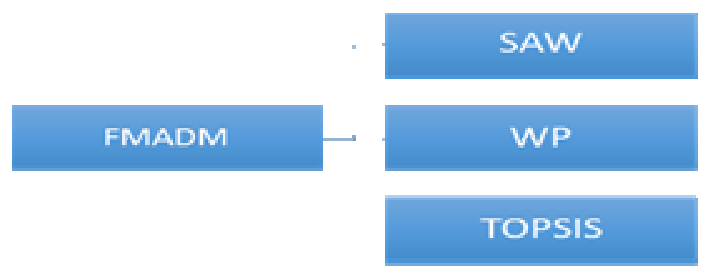

Fig. 4. FMADM applicator-based taxonomy

\section{CONCLUSION}

The MCDM method is not considered appropriate for decision making due to the uncertainty in results if incomplete information is provided. Fuzzy MCDM method has been developed as a solution to that issue. A short literature review is presented in this paper in an attempt to provide a taxonomy of fuzzy multi-attribute decision making systems in terms of model, inventor and data type.

\section{References}

[1] E. D. Rikhiana, A. Fadlil, "Implementasi Sistem Pakar Untuk Mendiagnosa Penyakit Dalam Pada Manusia Menggunakan Metode Dempster Shafer", Jurnal Sarjana Teknik Informatika, Vol. 1, No. 1, pp. $1-10,2013$

[2] Y. N. Istiqomah, A. Fadlil, "Sistem Pakar Untuk Mendiagnosa Penyakit Saluran Pencernaan Menggunakan Metode Dempster Shafer", Jurnal Sarjana Teknik Informatika, Vol. 1, No. 1, pp. 32-41, 2013

[3] P. Wijayanti, A. Fadlil, "Sistem Pakar Mendiagnosa Jenis Penyakit Stroke Menggunakan Metode Certainty Factor", Jurnal Sarjana Teknik Informatika, Vol. 2, No. 1, pp. 691-700, 2014

[4] M. J. Wahyudi, A. Fadlil, "Sistem Pakar Untuk Mengidentifikasi Penyakit Udang Galah Dengan Metode Theorema Bayes 1", Jurnal Sarjana Teknik Informatika, Vol. 1, No. 1, pp. 11-20, 2013

[5] S. Triyanto, A. Fadlil, "Sistem Pakar Untuk Mendiagnosa Penyakit Kelinci Berbasis Web”, Jurnal Sarjana Teknik Informatika, Vol. 2, No. 1, pp. 701-711, 2014

[6] S. Purnama, F. Firdausy, A. Yudhana, "Sistem Pakar Pendeteks Kerusakan Mesin Motor Menggunakan Borland Delphi 7", Telecommunication Computing Electronics and Control, Vol. 5, No. 1, pp. 33-38, 2007

[7] R. Umar, Sunardi, Y. B. Fitriana, "Taxonomy of Decision Support System Based on Software and Calculation Method", International Journal of Innovative Science and Research Technology, Vol. 2, No. 9, pp. 206-211, 2017

[8] O. E. Turban, J. E. Aronson, T. -P. Liang, Decision Support System and Intelligent Systems (Sistem Pendukung Keputusan dan Sistem Cerdas), Andi Publisher, 2005

[9] C. Chen, C. M. Klein, "An efficient approach to solving fuzzy MADM problems", Fuzzy Sets and Systems, Vol. 88, No. 1, pp. 51-67, 1997

[10] S. Kusumadewi, S. Hartati, A. Harjoko, R. Wardoyo, Fuzzy MultiAttribute Decision Making (FUZZY MADM), Graha Ilmu, 2006

[11] H. -J. Zimmermann, Fuzzy Sets Theory and Its Applications, Kluwer Academic Publishers, 1991

[12] D. Kartini, A. Saputra, O. Soesanto, "Implementasi Metode Fuzzy MADM Yager Pada Sistem Pendukung Keputusan Penentuan Keluarga Miskin (Studi Kasus : Desa Karang Rejo Kecamatan Jorong Kabupaten Tanah Laut)", Seminar Ilmiah Nasional Teknologi Komputer, Vol. 1, pp. $191-198,2015$ 
[13] R. B. Permana, "Pemilihan Pelanggan Terbaik Dengan Model Yager Pada PT. Aesha Surabaya", available at: http://ppta.stikom.edu/upload /upload/file/04410100234MAKALAH_TA.pdf

[14] H. Kwakernaak, "An algorithm for rating multiple-aspect alternatives using fuzzy sets", Automatica, Vol. 15, No. 5, pp. 615-616, 1979

[15] E. Prasetyo, "Fuzzy Database", available at: http://www.slideserve.com /moeshe/fuzzy-database, 2012

[16] C. Praseptyo, A. Pujiyanta, "Media Pembelajaran Himpunan Fuzzy Berbasis Multimedia”, Jurnal Sarjana Teknik Informatika, Vol. 2, No. 2, pp. 1176-1185, 2014

[17] I. Kaliszewski, D. Podkopaev, "Simple additive weighting-A metamodel for multiple criteria decision analysis methods", Expert Systems with Applications, Vol. 54, pp. 155-161, 2016

[18] Y. Melia, "Multi Attribute Decision Making Using Simple Additive Weighting and Weighted Product in Investment Introduction", International Academic Institutefor Science and Technology, Vol. 3, No. 7, pp. 1-15, 2016

[19] A. Ahmadi, D. T. Wijayanti, "Implementasi Weighted Product (WP) dalam Penentuan Penerima Bantuan Langsung Masyarakat PNPM Mandiri Perdesaan", Seminar Nasional Aplikasi Teknologi Informasi, pp. A19-A22, 2014 